DOI: https://doi.org/10.31073/abg.60.07

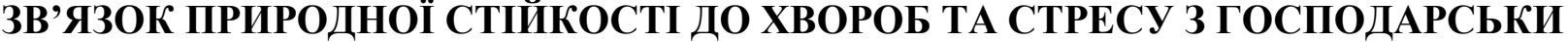 КОРИСНИМИ ОЗНАКАМИ МОЛОЧНОЇ ХУДОБИ
}

\author{
Н. М. МАКОВСЬКА, С. А. ЧУЛКОВ \\ Інститут розведення і генетики тварин імені М.В.Зубия НААН (Чубинське, Украӥна) \\ https://orcid.org/0000-0002-1973-814X-H. М. Маковська \\ https://orcid.org/0000-0002-6676-0980-C. А. Чулков \\ makovska.n@gmail.com
}

Вивчали зв'язок природної резистентності та стійкості до стресу телиць голштинської породи з господарськи корисними ознаками. Встановлено додатній корелячійний зв'язок між показниками середньомісячного приросту живої маси і показниками бактерицицної активності сироватки крові телят $(r=+0,28 \pm 0,13)$; додатню, проте не вірогідну, корелячію між живою масою у віці 2 та 7 міс. і показниками бактерицидної активності крові телят. Між живою масою у віці 7 місяиів і показниками лізоцимної активності сироватки крові встановлено від 'ємну кореляційну залежність $(r=-0,585 \pm 0,22 * *, P<0,01)$. Вплив продуктивності матерів на стійкість телят до стресу виявився статистично значущим (становив $\eta_{x}^{2}=39,5 \%$ ). У тварин, які в ранньому віці мали статус стрес-норма, рівень молочної продуктивності за 305 днів першої лактації був вірогідно вищим (+1843 кг, $P<0,05)$, ніж у стресчутливих тварин.

Ключові слова: природна резистентність, молочна худоба, господарськи корисні ознаки

\section{INTERRELATION OF NATURAL STABILITY TO RESISTANCE TO DISEASE AND STRESS WITH ECONOMICALLY USEFUL FEATURES IN DAIRY CATTLE}

\section{N. Makovska, S. Chulkov}

Institute of Animal Breeding and Genetics nd. a. M.V.Zubets of NAAS (Chubynske, Ukraine)

The connection of the nature resistance of Holstein breed's heifers with agricultural useful sign have been conducted. Positive correlation connection between indexes of average monthly increase of live weight and indexes of the bactericide activity of blood serum was $(r=+0.28 \pm 0.13)$. The positive, but not significant correlation between live weight at the age of 2 and 7 months and indexes of the lizocime activity of blood serum have been installed. Between live weight of heiters at the age of 7 months and indexes of the bactericide activity of blood serum were negative correlation dependence $(r=-0.585 \pm 0.22 * *, P<0,01)$ installed. The influence of mother's productivity on stress resistance of calves was statistically significant $\left(\eta_{x}{ }^{2}=39.5 \%\right)$. The animals which had normal status at an early age, have higher yield of milk on $1843 \mathrm{~kg}(P<0,05)$, then stress sensitive animals.

Keywords: nature resistance, dairy cattle, economically useful traits

\section{СВЯЗЬ ЕСТЕСТВЕННОЙ УСТОЙЧИВОСТИ К БОЛЕЗНЯМ И СТРЕССУ С ХОЗЯЙС- ТВЕННО-ПОЛЕЗНЫМИ ПРИЗНАКАМИ КРУПНОГО РОГАТОГО СКОТА}

\section{Н. Н. Маковская, С. А. Чулков}

Институт разведения и генетики животных имени М.В.Зубца НААН (Чубинское, Украина)

Изучалась связь естественной резистентности и стресустойчивости телок голштинской породы с хозяйственно-полезными признаками. Установлена положстельная корреляционная связь между среднемесячным приростом живой массы и бактерицидной активностью сыворотки крови телят ( $r=+0,28 \pm 0,13)$; положительная, однако не достоверная, корреляция между живой массой ві 2 и 7 мес. и показателями бактерицииной активности крови телят. Между живой массой в возрасте 7 месяцев и показателями лизоцимной активности 
сыворотки крови установлена отрицательная корреляционная зависимость $(r=-0,585 \pm 0,22 * *, P<0,01)$. Влияние продуктивности матерей на стойкость телят $\kappa$ стрессу оказалось статистично значимым $\left(\eta_{x}^{2}=39,5 \%\right)$. У животных, которые в раннем возрасте имели статус стрес-норма, уровень молочной продуктивности за 305 дней первой лактации был достоверно более высоким (+1843 к2, $P<0,05)$, чем у стресчувствительных жсивотных.

Ключевые слова: естественная резистентность, молочный скот, хозяйственно-полезные признаки

Вступ. В молочному скотарстві актуальним є питання збільшення життєздатності та збереженості молодняку. Вирішення цієї проблеми дозволяє не лише збільшити виробництво продукції, але й поповнити стадо високопродуктивними тваринами. Відомо про важливість материнського впливу на формування стійкості до хвороб у телят, проте існують індивідуальні розбіжності у напруженості колострального імунітету [1], що є передумовою для селекції. Встановлено додатній статистично значущий кореляційний зв'язок між імунобіологічними показниками крові телят та їх довічним надоєм у дорослому віці [2].

Відбір тварин за генетико-селекційними особливостями і показниками природної резистентності є важливим елементом при створенні нових та вдосконаленні існуючих порід великої рогатої худоби $[3,4]$. Стійкість до хвороб та імунний статус формується у ранньому віці, проте гематологічні показники вивчаються доволі рідко у порівнянні із показниками росту та розвитку в онтогенезі $[5,6]$.

Метою нашої роботи було вивчити зв’язок природної резистентності з господарськи корисними ознаками тварин голштинської породи.

Матеріали та методи досліджень. Дослідження проведено на тваринах голштинської породи в ПрАТ «Агро-Регіон». Використовували дані первинного селекційного та ветеринарного обліку в господарстві. Нами було сформована дослідна група телиць, батьком яких є бугай Нептун 8744362 (51 голова). Проводили облік захворюваності (захворіння неінфекційної етіології), вивчали динаміку живої маси телят, вивчали показники природної резистентності тварин. Як критерії природної резистентності визначали бактерицидну (БАСК) та лізоцимну активність сироватки крові (ЛАСК) [7, 8]. Для об'єктивної оцінки фагоцитозу враховували активність (ФА) та інтенсивність фагоцитозу (ІФ) [7].

Критерієм прогнозуючої оцінки племінних якостей у ранньому віці може бути i стресстійкість молодняку великої рогатої худоби, що визначається за еозинофільним тестом $[9,10)]$. Еозинофільний тест проводили за методикою, що описана в літературі $[9,11]$. Крім того, аналізували показники молочної продуктивності матерів телят дослідної групи за лактацію, яка настала після народження телят дослідної групи. Також досліджували продуктивні ознаки дослідної групи тварин після закінчення ними першої лактації.

Статистичну обробку даних проводили на ПК за використання програми Microsoft Exel та методик Н. А. Плохинского [12]. Використані наступні позначення рівнів статистичної значущості: * - $\mathrm{P}<0,05, * *-\mathrm{P}<0,01, * * *-\mathrm{P}<0,001$.

Результати досліджень. Показники гуморального імунітету продемонстрували доволі високу мінливість, що підтверджується коефіцієнтом мінливості (табл. 1). Значення ЛАСК у піддослідних тварин знаходились в межах 1,4\%-83,1\%, а загальної БАСК - 2,6-82\%. В той же час індивідуальні коливання фагоцитарної активності 46-56\%. Встановлено додатню кореляцію між живою масою у віці 2 та 7 міс і показниками БАСК $(\mathrm{r}=+0,172 \pm 0,24$ та 0,284 $\pm 0,26$, відповідно) (табл. 2). 3 іншого боку, між живою масою у віці 2 та 7 місяців і показниками ЛАСК встановлено негативну кореляційну залежність $(\mathrm{r}=-0,009 \pm 0,24$ i $-0,585 \pm 0,22 * *$, відповідно), що узгоджується 3 даними літератури [13]. Встановлено пряму кореляційну залежність між гуморальними та клітинними факторами імунітету телят та продуктивністю у дорослому віці (надій за 305 днів першої лактації). Причому коефіцієнт коре- 
ляції для ФА виявився найменшим, що узгоджується із даними літератури [2]. Проте, на відміну від інших авторів, які встановили залежність першого порогу вірогідності, в нашому випадку коефіцієнт кореляції не досягав статистично значущого рівня.

1. Характеристика біологічних показників піддослідни телят голштинської породи в ПрАТ «Агро-Реzіон»

\begin{tabular}{|l|r|r|}
\hline \multicolumn{1}{|c|}{ Показник Фактори неспецифічної резистентності до захворювань } \\
\hline \multicolumn{1}{|c|}{ Ф } & $15,46 \pm 4,01$ & 1,13 \\
\hline Еозинофілів в 1 мл крові & $52,50 \pm 0,81$ & 0,07 \\
\hline Фагоцитарна активність (ФА \%) & $3,46 \pm 0,09$ & 0,12 \\
\hline Інтенсивність фагоцитозу мк. кл/кл & $34,81 \pm 1,95$ & 0,62 \\
\hline БАСК \% & $21,70 \pm 0,90$ & 0,99 \\
\hline ЛАСК \% & $52,25 \pm 0,28$ & 0,04 \\
\hline \multicolumn{1}{|c|}{ Динаміка живої маси, кг } \\
\hline Жива маса кг 2 міс. & $75,46 \pm 0,31$ & 0,03 \\
\hline Жива маса кг 3 міс. & $101,04 \pm 0,37$ & 0,03 \\
\hline Жива маса кГ 4 міс. & $124,75 \pm 0,39$ & 0,02 \\
\hline Жива маса кг 5 міс. & $149,36 \pm 0,29$ & 0,01 \\
\hline Жива маса кг 6 міс. & $179,12 \pm 0,32$ & 0,02 \\
\hline Жива маса кг 7 міс. & $384,01 \pm 0,45$ & \\
\hline Жива маса при 1 осіменінні & \\
\hline
\end{tabular}

2. Кореляційна залежність міжс показниками неспецифічної резистентності та живої маси телят у різному віці

\begin{tabular}{|c|c|c|c|c|c|c|}
\hline \multirow{2}{*}{ ФА } & \multirow{2}{*}{ ЛАСК } & \multirow{2}{*}{$\begin{array}{c}\text { Надій } \\
\text { первісток }\end{array}$} & & новонароджені & 2 міс. & 7 міс. \\
\hline ФА & & & $0,19 \pm 0,26$ & $-0,146 \pm 0,24$ & $0,110 \pm 0,24$ & $0,695 \pm 0,18^{* * *}$ \\
\hline БАСК & $0,827 \pm 0,14 * * *$ & $-0,153 \pm 0,24$ & $0,27 \pm 0,26$ & $-0,514 \pm 0,21 *$ & $0,172 \pm 0,24$ & $0,284 \pm 0,26$ \\
\hline ЛАСК & $-0,132 \pm 0,24$ & & $0,30 \pm 0,25$ & $-0,104 \pm 0,24$ & $-0,009 \pm 0,24$ & $-0,585 \pm 0,22 * *$ \\
\hline
\end{tabular}

Встановлені високі показники вікової повторюваності показників живої маси у всі вікові періоди $(\mathrm{r}=+0,8-+0,9)$, що вказує на стабільність вирощування телят. Інтенсивність нарощування живої маси з віком закономірно знижується від 44,5\% (період 2-3 міс.) до 19,8\% (період 5-6 міс.). У період 6-7 міс. відносний приріст живої маси становить 19,9\%.

Середньомісячний приріст живої маси в дослідній групі становив 25,3 $\pm 1,18$ кг. Встановлено додатній кореляційний зв'язок між показниками середньомісячного приросту живої маси і показниками БАСК $(\mathrm{r}=+0,28 \pm 0,13)$. 3 іншого боку, між показниками ЛАСК і середньомісячним приростом живої маси встановлено обернену кореляцію $(\mathrm{r}=-0,38 \pm 0,12)$.

За еозинофільним тестом стресстійких тварин в дослідній групі не виявлено, що ми пояснюємо недостатньо сформованою захисною системою та адаптаційними можливостями організму тварин, 60\% дослідних телят мали статус стрес-норма, а 40\% - стрес-чутливі.

Загалом по стаду захворюваність на гастроентерит у ранньому віці спостерігалась у 5$7 \%$ особин, на пневмонію - у 2-3\% тварин. В дослідній групі зафіксовано захворювання: гастроентерит - 11,5\% (6 голів), тимпанія - 13,5\% (7 голів), кератокон'юктивіт - 19,1\% (10 голів). На пневмонію тварини дослідної групи не хворіли.

Силу впливу показників природної резистентності до захворювань на молочну продуктивність первісток вивчали за використання дисперсійного аналізу. 3 даних літератури [1] відомо про вірогідний вплив батька на захворюваність корів $(2,9-5,3 \%)$. В наших дослідженнях для нівелювання впливу батька у дослідну групу було відібрано лише телиць від Нептуна 8744362.

Матерями піддослідних телят переважно були повновікові корови (в середньому, на третій лактації). Лише 15\% телят одержані від первісток. Відомо про вплив матерів не лише на ріст та розвиток, схильність до хвороб телят, а й на майбутню продуктивність у дорослому віці [14]. Вивчали вплив продуктивності матері по лактації, що передувала отеленню, в результаті 
якого отримано досліджуваних телят. Вивчали вплив рівня молочної продуктивності матері на живу масу при народженні, живу масу у віці 7 місяців, стійкість до стресу та на неспецифічну резистентність телят у дослідній групі.

Вплив продуктивності матерів на живу масу телят при народженні становив 6,3\%, але був не достовірним, у віці 6 місяців був вірогідним і становив $\eta_{\mathrm{x}}{ }^{2}=29,6 \%(\mathrm{P}>0,001)$ (табл. 3 ). Що узгоджується 3 даними літератури $[15,16]$ про відсутність суттєвого зв'язку живої маси телят при народженні з молочною продуктивністю корів-матерів. Сила впливу порядкового номеру отелення на масу телят при народженні становила $\eta_{\mathrm{x}}{ }^{2}=2 \%$, але була не вірогідна. На показники неспецифічної резистентності телят достовірного впливу продуктивності матерів не виявлено. Вплив продуктивності матерів на стійкість телят до стресу виявився статистично значущим і становив $\eta_{\mathrm{x}}{ }^{2}=39,5 \%(\mathrm{P}<0,05)$.

3. Вплив продуктивності матерів на біологічні показники телят

\begin{tabular}{|l|c|c|c|}
\hline \multicolumn{1}{|c|}{ Показник } & $\eta_{\mathrm{x}}{ }^{2}$ & $\mathrm{~F}$ & $\mathrm{P}$ \\
\hline Жива маса телят при народженні & 0,063 & 0,35 & 0,1 \\
\hline Жива маса телят у віці 7 місяців & $0,296^{* * *}$ & 4,68 & 0,001 \\
\hline БАСК & 0,095 & 0,74 & 0,1 \\
\hline ЛАСК & 0,041 & 0,38 & 0,1 \\
\hline ФА & 0,19 & 1,99 & 0,1 \\
\hline Стійкість до стресу & $0,395^{*}$ & 3,5 & 0,05 \\
\hline
\end{tabular}

Не встановлено статистично значущого впливу віку першого осіменіння дослідних тварин $\left(\eta_{\mathrm{x}}{ }^{2}=12,3 \%\right)$ та захворюваності в ранньому віці тварин на рівень їхньої молочної продуктивності $\left(\eta_{\mathrm{x}}^{2}=7 \%\right)$.

Провели порівняльне дослідження деяких господарськи корисних ознак в групі дослідних тварин та їх ровесників (табл. 4). Вивчали вплив природної стійкості до захворювань та стресстійкості телят на продуктивність по першій лактації у дорослому віці.

4. Вилив резистентності та стресстійкості на господарськи корисні ознаки тварин ПрАТ «Агро-Регіон»

\begin{tabular}{|c|c|c|c|c|c|}
\hline \multirow{3}{*}{ Показник } & \multicolumn{4}{|c|}{ Дослідна група } & \multirow{3}{*}{$\begin{array}{c}\text { В серед- } \\
\text { ньому } \\
\text { щодо стада }\end{array}$} \\
\hline & \multicolumn{2}{|c|}{ щодо хвороб в ранньому віці } & \multicolumn{2}{|c|}{ щодо впливу стресорів } & \\
\hline & хворіли & не хворіли & чутливі & норма & \\
\hline Кількість тварин, гол. & 23 & 28 & 19 & 32 & 120 \\
\hline Жива маса у 2 міс., кг & $50,7 \pm 0,33$ & $53,5 \pm 0,25 * * *$ & $50,7 \pm 0,07$ & $53 \pm 0,05 * *$ & $51,9 \pm 0,07$ \\
\hline Надій 305 днів, кг & $7578 \pm 470$ & $7454 \pm 333$ & $5669 \pm 435$ & $7512 \pm 545^{*}$ & $6589 \pm 177$ \\
\hline Вміст жиру в молоці, \% & $3,78 \pm 0,02$ & $3,82 \pm 0,02$ & $3,69 \pm 0,04$ & $3,83 \pm 0,04 * *$ & $3,72 \pm 0,01$ \\
\hline Вміст білка в молоці, \% & $3,1 \pm 0,02 *$ & $3,06 \pm 0,01$ & $3,02 \pm 0,03$ & $3,1 \pm 0,02 *$ & $3,04 \pm 0,02$ \\
\hline Вік першого осіменінні, міс. & $26,6 \pm 0,61$ & $27,3 \pm 0,50$ & $25,3 \pm 0,59 *$ & $27,0 \pm 0,64$ & $25,8 \pm 0,48$ \\
\hline
\end{tabular}

Порівнянням рівнів молочної продуктивності тварин, які в ранньому віці мали різний стрес статус, виявлено, що в тварин, які в ранньому віці мали статус стрес-норма, рівень молочної продуктивності був вірогідно вищим на 1843 кг (Р < 0,05), ніж у стресчутливих тварин. Також стресстійкі телята характеризувалися вірогідно більшою живою масою. Телята, що виявилися чутливими до стресу, мали менший вік першого осіменіння за першого порогу вірогідності. Встановлено статистично значущу різницю за живою масою у віці 2 місяці у тварин, що в ранньому віці перенесли захворювання та тварин, що не хворіли. Вірогідної різниці між продуктивністю первісток двох груп не виявлено.

Висновки. Встановлено зв'язок природної резистентності з господарськи корисними ознаками тварин голштинської породи. Встановлено додатній кореляційний зв'язок між показниками середньомісячного приросту живої маси і показниками БАСК $(\mathrm{r}=+0,28 \pm 0,13)$. Вплив продуктивності матерів на стійкість телят до стресу виявився статистично значущим $і$ становив $\eta_{\mathrm{x}}{ }^{2}=39,5 \%$. Порівнянням рівнів молочної продуктивності тварин, які в ранньому віці мали різний стрес статус, виявлено, що у тварин, які в ранньому віці мали статус стрес- норма, 
рівень молочної продуктивності був вірогідно вищим на 1843 кг (Р < 0,05), ніж у стресчутливих тварин.

Отже, існування співвідносної мінливості між живою масою телят та показниками природної резистентності потрібно враховувати при селекції великої рогатої худоби на стійкість до захворювань.

\section{БІБЛІОГРАФІЯ}

1. Карликов Д. В. Селекция скота на устойчивость к заболеваниям. Москва : Россельхозиздат, 1984. 187 с.

2. Milostiviy R., Antonenko P., Kostyuk V., Vasilrnko T., Czerniawska-Platkowska E. The milk yield of Ukrainian Holstei is related to the immunobiological parameters of blood of calves. Folia Pomer. Univ. Technol. Stetin., Agric., Aliment., Pisc., Zootech. 2018. № 345(48) 4. P. 105-112. DOI: 10.21005/AAPZ2018.48.4.10.

3. Сірацький Й. 3. Федорович Є. І. Адаптаційні особливості тварин української чорно-рябої молочної породи. Вісник аграрної науки. 2002. № 9. С. 24-28

4. Красота В. Ф. Некоторые аспекты повышения естественной резистентности молочного скота, птицы и пушных зверей. Сельскохозяйственная биология. 1985. № 5. С. 58-64.

5. De Paula M. R., Oltramari C. E., Silva J. T., Gallo M. P. C., Mourao G. B., Bittar C. M. M. Intensive liguid feeding of dairy calves with a medium crude protein milk replacer: Effects on performance, rumen, and blood parameters. J. of Dairy Sciense. 2017. № 100 (6). P. 4448-4456. DOI: 10.3168/JDS.2016-10859

6. Mirzaei M., Dadkhah N., Baghbanzadeh-Nobari B., Agha-Tehrani A., Eshraghi M., Imani M., Ghaffari M. H. Effects of preweaning total plane of milk intake and weaning age on intake, growth performance, and blood metabolites of dairy calves. J. of Dairy Sciense. 2018. № 101 (5). P. $4212-$ 4220. DOI: 10.3168/JDS.2017-13766.

7. Чумаченко В. Е., Высоцкий А. М. Определение естественной резистентности и обмена веществ у сельскохозяйственных животных. Киев : Урожай, 1990. 136 с.

8. Федорович С. І. Вікова динаміка природної резистентності телиць чорно - рябої породи західного регіону України. Розведення і генетика тварин. Київ : Аграр. наука, 2003. Вип. 35. C. 141-145.

9. Зубець М. В., Буркат В. П., Єфіменко М. Я., Подоба Б. Є., Коновалов В. С., Антоненко В. І., Гавриленко М. С., Гузєв І. В., Дзіцюк В. В., Кругляк А. П., Чернякова Н. С., Демчук М. П., Пахолюк В. С., Стоянов Р. О., Заблудовський С. Є. Генетико-селекційний моніторинг у молочному скотарстві. Київ : Аграр. наука, 1999. 88 с.

10. Юрьев Е. А., Кортиков А. В., Чуякова Н. В. Стресс сельскохозяйственных животных. Ветеринария сельскохозяйственных животных. 2007. № 2. С. 3-8.

11. Устинов Д. А. Методические рекомендации по определению возникновения и развития стрессов у поросят с помощью эозинофильного теста. Дубровицы, 1978. 26 с.

12. Плохинский Н. А. Руководство по биометрии для зоотехников. Москва : Колос, 1969. $256 \mathrm{c}$.

13. Сірацький Й. 3. Федорович С. І. Селекційні та біологічні особливості тварин західного внутрішньопородного типу української чорно-рябої молочної породи. Розведення $і$ генетика тварин. Київ : Аграр. наука, 2007. Вип. 41. С. 244-254.

14. Cummins C., Berry D. P., Murphy J. P., Lorenz I., Kennedy E. The effect of colostrum storage conditions on dairy heifer calf serum immunoglobulin $\mathrm{G}$ concentration and preweaning health and growth rate. J. of Dairy Sciense. 2017. № 100 (1). P. 525-535. DOI: 10.3168/JDS.2013-7494.

15. Вацький В. Ф., Величко С. А. Вплив окремих факторів на масу телят при народженні і молочну продуктивність їх матерів. Вісник Полтавської державної аграрної академії. 2012. № 1. С. 115-118.

16. Музика Л. І., Кос В. Ф., Жмур А. Й. Продуктивність та племінні якості корів української чорно-рябої молочної породи залежно від їх живої маси при народженні. Науковий вісник 
Львівського національного університету ветеринарної медицини та біотехнологій ім. С. 3. Гљииького. 2010. Т. 12, № 2 (44), ч. 3. С. 140-143.

\section{REFERENCES}

1. Karlikov, D. V. 1984. Selekcija skota na ustojchivost' $k$ zabolevanijam - Breeding livestock for disease resistance. Moskva : Rossel'hozizdat, 187. (in Russian).

2. Milostiviy, R., P. Antonenko, V. Kostyuk, T. Vasilrnko, and E. Czerniawska-Platkowska. 2018. The milk yield of Ukrainian Holstei is related to the immunobiological parameters of blood of calves. Folia Pomer. Univ. Technol. Stetin., Agric., Aliment., Pisc., Zootech. 345(48)4:105-112. DOI: 10.21005/AAPZ2018.48.4.10. (in English).

3. Sirats'kyy, H. Z., and Ye. I. Fedorovych. 2002. Adaptatsiyni osoblyvosti tvaryn ukrayins'koyi chorno-ryaboyi molochnoyi porody - Adaptation of specialties of the Ukrainian Black-and-White Dairy breed. Visnyk ahrarnoyi nauky - Bulletin of agrarian science. 9:24-28 (in Ukrainian).

4. Krasota, V. F. 1985. Nekotorye aspekty povyshenija estestvennoj rezistentnosti molochnogo skota, pticy i pushnyh zverej - Some aspects of increasing the natural resistance of dairy cattle, poultry and fur animals. Sel'skohozjajstvennaja biologija - Agriculural Biology. 5:58-64 (in Russian).

5. De Paula, M. R., C. E. Oltramari, J. T. Silva, M. P. C. Gallo, G. B. Mourao, and C. M. M. Bittar. 2017. Intensive liguid feeding of dairy calves with a medium crude protein milk replacer: Effects on performance, rumen, and blood parameters. J. of Dairy Sciense. 100(6):44484456. DOI: 10.3168/JDS.2016-10859 (in English).

6. Mirzaei, M., N. Dadkhah, B. Baghbanzadeh-Nobari, A. Agha-Tehrani, M. Eshraghi, M. Imani, and M. H. Ghaffari. 2018. Effects of preweaning total plane of milk intake and weaning age on intake, growth performance, and blood metabolites of dairy calves. J. of Dairy Sciense. 101(5):4212-4220. DOI: 10.3168/JDS.2017-13766. (in English).

7. Chumachenko, V. E., and A. M. Vysockij. 1990. Opredelenie estestvennoj rezistentnosti $i$ obmena veshhestv u sel'skohozjajstvenny zhivotnyh - Determination of natural resistance and metabolism in farm animals. Kiev, Urozhaj, 136 (in Russian).

8. Fedorovych, Ye. I. 2003. Vikova dynamika pryrodnoyi rezystentnosti telyts' chorno - ryaboyi porody zakhidnoho rehionu Ukrayiny - Dynamics of natural resistance of the heifer Black-and-White breed of the western region of Ukraine. Rozvedennya i henetyka tvaryn - Animal Breeding and Genetics. Kyyiv: Ahrar. nauka, 35:141-145 (in Ukrainian).

9. Zubets', M. V., V. P. Burkat, M. Ya. Yefimenko, B. Ye. Podoba, V. S. Konovalov, V. I. Antonenko. M. S. Havrylenko, I. V. Huzyev, V. V. Dzitsyuk, A. P. Kruhlyak, N. Ye. Chernyakova, M. P. Demchuk, V. S. Pakholyuk, R. O. Stoyanov, and Ye. Ye. Zabludovs'kyy. 1999. Henetyko-selektsiynyy monitorynh u molochnomu skotarstvi - Genetic breeding monitoring in dairy cattle. Kyyiv : Ahrar. nauka, 88 (in Ukrainian).

10. Jur'ev, E. A., A. V. Kortikov, and N. V. Chujakova. 2007. Stress sel'skohozjajstvennyh zhivotnyh - Stress of farm animals. Veterinarija sel'skohozjajstvennyh zhivotnyh - Veterinary of agricultural animals. 2:3-8 (in Russian).

11. Ustinov, D. A. 1978. Metodicheskie rekomendacii po opredeleniju vozniknovenija i razvitija stressov u porosjat s pomoshh'ju jeozinofil'nogo testa - Methodological recommendations for determining the occurrence and development of stress in piglets using an eosinophilic test. Dubrovicy, 26 (in Russian).

12. Plohinskij, N. A. 1969. Rukovodstvo po biometrii dlja zootehnikov-Biometrics guide for livestock specialists. M. : Kolos, 256 (in Russian).

13. Sirats'kyy, J. Z., and Ye. I. Fedorovych. 2007. Selektsiyni ta biolohichni osoblyvosti tvaryn zakhidnoho vnutrishn'oporodnoho typu ukrayins'koyi chorno-ryaboyi molochnoyi porody - Selection and biological peculiarities of animals of the western domestic type of the Ukrainian Black-and-White Dairy breed. Rozvedennya i henetyka tvaryn - Animal Breeding and Genetics. Kyyiv : Ahrar. nauka, 41:244-254 (in Ukrainian). 
14. Cummins, C., D. P. Berry, J. P. Murphy, I. Lorenz, and E. Kennedy. 2017. The effect of colostrum storage conditions on dairy heifer calf serum immunoglobulin $\mathrm{G}$ concentration and preweaning health and growth rate. J. of Dairy Sciense. 100(1):525-535. DOI: 10.3168/JDS.2013-7494 (in English).

15. Vats'kyy, V. F., and S. A. Velychko. 2012. Vplyv okremykh faktoriv na masu telyat pry narodzhenni i molochnu produktyvnist' yikh materiv - Infusion of factors on the weight of calves with the population and milk productivity of their mothers. Visnyk Poltavs'koyi derzhavnoyi ahrarnoyi akademiyi - Bulletin of Poltava state agrarian academy. 1:115-118 (in Ukrainian).

16. Muzyka, L. I., V. F. Kos, and A. Y. Zhmur. 2010. Produktyvnist' ta pleminni yakosti koriv ukrayins'koyi chorno-ryaboyi molochnoyi porody zalezhno vid yikh zhyvoyi masy pry narodzhenni - Productivity and breed quality of Ukrainian Black-Spotted dairy breed depending on their living at birth. Naukovyy visnyk L'vivs'koho natsional'noho universytetu veterynarnoyi medytsyny ta biotekhnolohiy im. S. Z. Hzhyts'koho - Scientific Messenger of Lviv National Universiti of Veterinary Medicine and Biotechnologies S. Z. Zhitsky. 12, 2(44):3:140-143 (in Ukrainian).

Одержано редколегією 10.09.2020 p.

Прийнято до друку 01.10.2020 p. 